Ann. Biol. anim. Bioch. Biophys., 1979, 19 (4 A), 1109-1121.

\title{
Electrical activity of the gallbladder and biliary tract in sheep and its relationships with antral and duodenal motility
}

\author{
par L. BUENO, Françoise PRADDAUDE \\ with the fechnical assistance of J. P. SERTHELON \\ Laborotoire de Physio-Pathologie Digestive, I.N.R.A., \\ Ecole Nationale Vétérinaire, \\ 23 Chemin des Capelles 31076, Toulouse Cedex, France.
}

Summary. The electrical activity of the gallbladder, biliary tract and gastroduodenal junction was recorded in conscious sheep by means of chronically implanted electrodes and was related to movements of the wall for both the antrum and duodenum.

Electromyograms of the gallbladder presented isolated spike potentials lasting 0.5 $1.5 \mathrm{sec}$. and occurring in series of 40 to 50 in $6-8 \mathrm{~min}$ regular periods at a mean frequency of 5 cycles/hr, correlated with slow contractile changes in the wall, or in long irregular periods $(50-80 \mathrm{~min})$ independently of the feeding behaviour.

The presence of propagated bursts of spikes along the cystic and common bile ducts was correlated with those of the proximal duodenum. Bile was delivered into the duodenum just before the arrival of a bolus of digesta at this level.

Cholecystokinine (CCK) as well as its synthetic octapeptide (CCK-OP) produced a primary gallbladder response in the form of long-burst potentials lasting 20-30 sec and then increasing in frequency. The relative potency was $1 \mathrm{ug}$ of CCK-OP equivalent to 2.5 ID units of extracted CCK.

Both $\alpha$-adrenergic and cholinergic substances produced an increase in spiking activity, whereas $\beta$-adrenergic substances inhibited this activity. Concomitant stimulation of the two types of receptors by adrenaline had an inhibitory action.

\section{Introduction.}

The ruminant gallbladder has been considered for a long time to be incapable of spontaneous contraction under physiological conditions (Magee, 1965). However, Caple and Heath (1971) observed spontaneous variations of gallbladder intraluminal pressure which they attributed to the motility of that organ. Nejmark (1977) studying sheep recently described the relationships between these pressure changes, the mechanical activity of the Oddi's sphincter and the movements of bile through the biliary tract. That author also noted the presence of slow, periodic pressure fluctuations due to changes in the tonus of the gallbladder. Furthermore, comparative cholecystography has revealed spontaneous changes in gallbladder volume (Caroli 
et al., 1956). However, Ludwick and Bass (1967) studying monkeys and dogs did not record any evidence of electrical or mechanical gallbladder activity, except for a slight rise in pressure just after feeding in dogs. Similar results were obtained in pigs, for which only an antral-like activity, considered to be an artefact, was recorded (Laplace, 1976).

It has been recently shown in anaesthetized sheep that both vagal stimulation and the administration of CCK or pentagastrin in vivo can induce an increase in intraluminal gallbladder pressure due to the contractile activity of that organ ; this would represent the mechanism involved in the post-feeding response (Pass and Heath, 1977). It was previously proposed that the mechanism of bile excretion involved the pressure gradient between the biliary tract and the duodenum. This has been attributed to the coordinated motor activity of the cystic and common bile ducts with that of the sphincter of Oddi (Mallet-Guy et al., 1933 ; Wyatt, 1967 ; Sarles et al., 1975 ; Nejmark, 1977). No morphological differences in the biliary tract of ruminant and monogastric species have been detected (Boyden, 1965). However, the continuous gastric emptying of ruminants indicates that their biliary excretion and gallbladder emptying may not be limited to the post-feeding period (Harrisson, 1962). This is confirmed by the fact that feeding does not induce changes in the duodenal motility in sheep (Bueno ef al., 1975) and by the observation of cyclic gallbladder pressure changes (Caple and Heath, 1971).

The aims of this work were (i) to demonstrate that the gallbladder has electrical activity and to determine its mechanical significance and nycthemeral organization ; (ii) to ascertain how this activity is related to that of the rest of the biliary tract, and (iii) to investigate the nature of the extrinsic nervous and gastro-intestinal hormones influencing gallbladder electrical activity.

\section{Material and methods.}

Animal preparation. - Six Lacaune ewes weighing $35-50 \mathrm{~kg}$, housed in melabolism cages, and receiving hay and water ad libitum were used for these experiments.

Surgery was performed aseptically in the fasted animal under thiopental anaesthesia $(20 \mathrm{mg} / \mathrm{kg} \mathrm{IV})$. Access to the gallbladder and the biliary tract was achieved by a $20-25 \mathrm{~cm}$ incision along the right hypochondrium. Ten groups of nickel-chromium electrodes were chronically implanted using a technique previously described for the small intestine (Ruckebusch, 1973) at the following sites : two groups on the gallbladder (apical pole and neck), one on the cystic duct and two others on the common bile duct at 1 and $4 \mathrm{~cm}$, respectively, from the junction of the ducts. Six additional groups were implanted on the abomasal antrum and the duodenal bulb at 5 and $0.5 \mathrm{~cm}$, respectively, from the pylorus, on the duodenum (at $5 \mathrm{~cm}$ on either side of Oddi's sphincter), and on the proximal jejunum at 3 and $4 \mathrm{~m}$ from the ligament of Treitz.

In 2 of the sheep, two strain gauges were attached, one on the gallbladder at an equal distance from its poles and on the antihepatic border, and the other on the greater curvature of the abomasum at $5 \mathrm{~cm}$ from the pylorus, the sensitive elements being placed transversally to the longer axis of the organ. A silastic catheter $(3 \mathrm{~mm}$ in diameter) was fixed in the duodenal lumen of all animals at $30 \mathrm{~cm}$ from the pylorus. 
Recordings. - The electrical activity was recorded from the free end of the electrodes connected to an EEG machine (Reega XII, Alvar, 93 Montreuil). The electromyograms were registered daily (time constant : $0.1 \mathrm{sec}$.) during periods of $8 \mathrm{hrs}$, with a paper speed of 4.5 and $7.2 \mathrm{~cm} / \mathrm{min}$. or recorded continuously after summation of the spike bursts at $20 \mathrm{sec}$. intervals on a multichannel potentiometric recorder, at a low paper speed $(9 \mathrm{~cm} / \mathrm{hr}$ ) (Latour, 1973). Simultaneous recording of strain gauge tensions (mecanogram) and corresponding electromyograms were made continuously on a rectilinear pen polygraph (Physio IV, Narco Bio-Systems, Texas).

Experimental procedure. - Starting 48 hrs after surgery, electrical activity was recorded during 30 to 40 days. After an 8 to 10-day control period, the animals were fasted for $72 \mathrm{hrs}$ to analyze the effect of the digesta flow on the gallbladder activity. Five days after feeding they received CCK-PZ (GIH, Stockholm) and CCK-OP (Kinevac N. D.) intravenously at doses of 0.5-1-4 lvy Dog Units $/ \mathrm{kg}$ and $0.1-0.2 \mathrm{mcg} / \mathrm{kg}$, respectively. The effects of these administrations were compared to those of duodenal acidification by a hydrochloric acid $(0.1 \mathrm{~N}, 2 \mathrm{ml} / \mathrm{min}$.). Nervous orthosympathetic sensitivity of the gallbladder was tested by intravenous administration of the following substances adrenaline, isoprenaline phenylephrine at 3,5 and $150 \mathrm{mcg} / \mathrm{kg}$, respectively. The effects of neostigmin (Prostigmine N. D., $40 \mathrm{mcg} / \mathrm{kg} \mathrm{IV)} \mathrm{and} \mathrm{of} \mathrm{atropine} \mathrm{sulfate}$ $(0.1$ and $0.5 \mathrm{mg} / \mathrm{kg}$ IV) were also investigated.

\section{Results.}

Gallbladder electromyogram. - The electrical activity of the gallbladder apex showed rapid isolated potentials $(200-250 \mu \mathrm{V})$, each lasting 0.5 to $1.5 \mathrm{sec}$. They appeared in cyclic periods (type A) or dispersed (type B) at a frequency of 5 and $13 / \mathrm{min}$., without direct propagation on the vesicular body (fig. 1, table 1) ; these rhythmic phases of the apical pole had a mean duration of $6.2 \pm 1.9 \mathrm{~min}$. and appeared at a frequency of $4.9 \pm 0.3 / \mathrm{hr}$ (table 1 ). In type B, the periods of activity lasted 60 to $80 \mathrm{~min}$., and were separated by short quiescent periods (5-15 min.).

\section{TABLE 1}

Characteristics of two types of gallbladder apex electrical activity :

Short cycles (A) and long, irregular cycles (B) (mean \pm S. D.)

\begin{tabular}{|c|c|c|c|c|}
\hline & \multicolumn{2}{|c|}{ Bursts } & \multicolumn{2}{|c|}{ Phases } \\
\hline & $\begin{array}{l}\text { Frequency } \\
(/ \min )\end{array}$ & $\begin{array}{l}\text { Duration } \\
\text { (sec) }\end{array}$ & $\begin{array}{l}\text { Number } \\
(/ \mathrm{h})\end{array}$ & $\begin{array}{l}\text { Duration } \\
\text { (min) }\end{array}$ \\
\hline $\begin{array}{l}A(n=50) \ldots \ldots \\
B(n=60) \ldots \ldots\end{array}$ & $\begin{array}{r}12.8 \pm 2.8 \\
5.1 \pm 1.9(1)\end{array}$ & $\begin{array}{l}1.3 \pm 0.5 \\
1.0 \pm 0.4\end{array}$ & $\begin{array}{l}4.9 \pm 0.3 \\
0.9 \pm 0.1\end{array}$ & $\begin{array}{c}6.2 \pm 1.9 \\
74.9 \pm 29.5\left({ }^{2}\right)\end{array}$ \\
\hline
\end{tabular}

( $\left.{ }^{1}\right)$ Significant difference $(P<0.05)$ from value observed for cyclic activity $(A)$. record.

(2) Interval between two consecutive periods of low-level activity on the gallbladder integrated 
(1)

apex

neck,

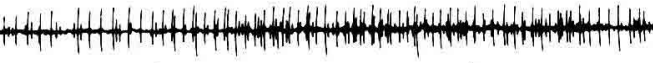

(1)<smiles>[Li][14CH3]</smiles>

Hepex

B

Hox neck

$1 \mathrm{~min}$

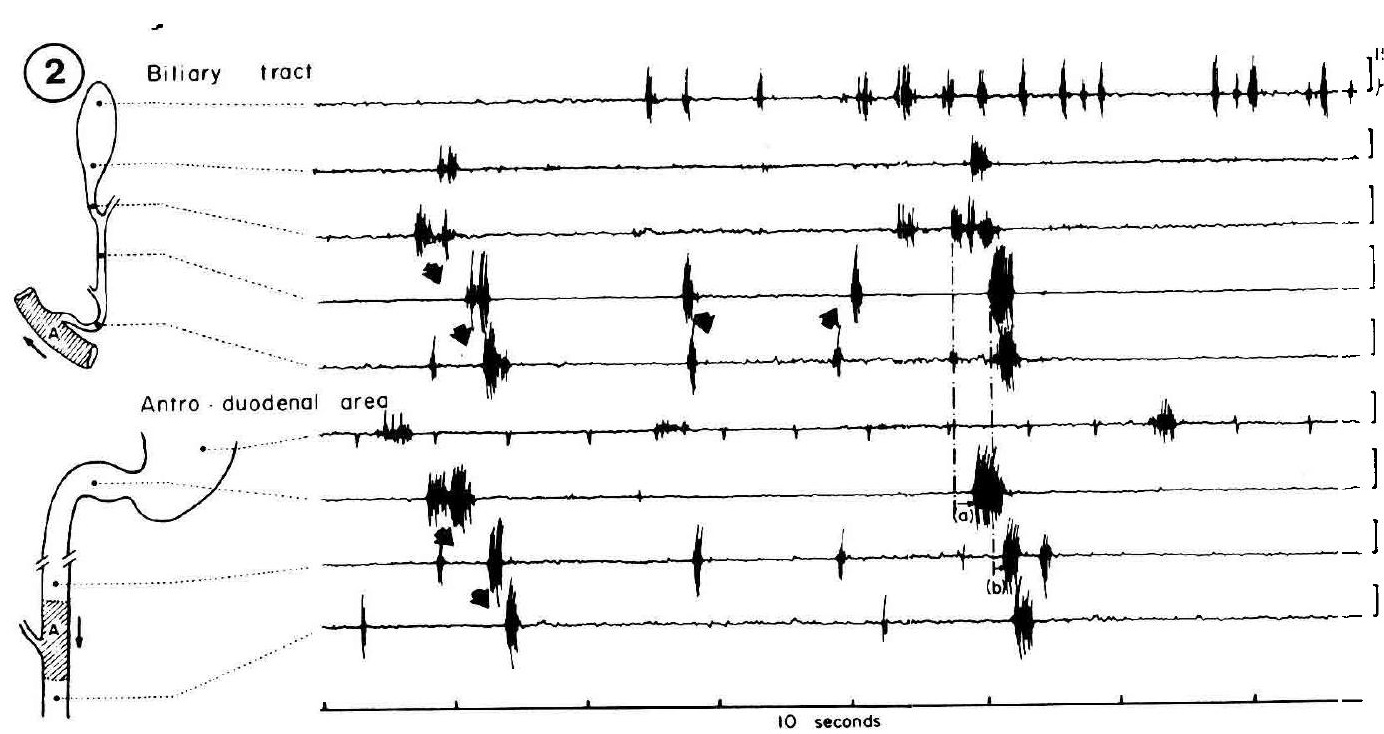

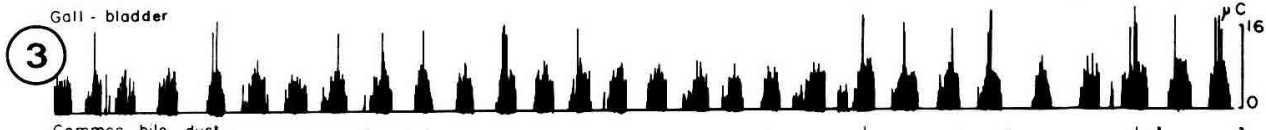

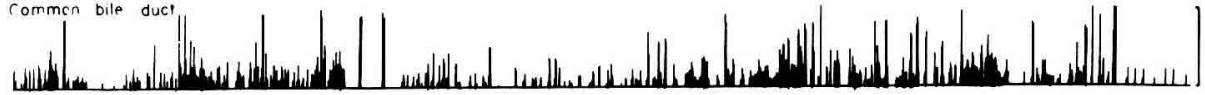

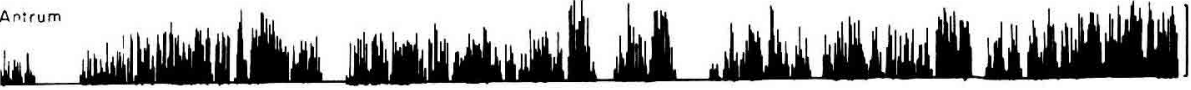
Duodenal bulb

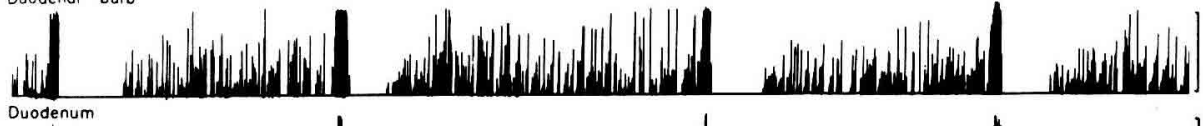
Prox | vejunum 
Electrical activity of the neck of the gallbladder presented the same basic isolated spikes as at the apex, and was grouped in short phases lasting 1 to $2 \mathrm{~min}$. The electromyogram also presented rhythmical series of 15 to 20 bursts of spikes $(6-10 \mathrm{~Hz})$, occurring after the end of a period of apical activity and in association with the beginning of a myoelectric complex.

Biliary tract and duodenal coordination. - The biliary tract (cystic and common bile ducts) presented bursts of high amplitude potentials (200-300 $\mu \mathrm{V}$ ) which were either isolated and localized in the common bile duct with a high percentage (42 p. 100) of retrograde propagations (fig. 2), or cyclically propagated from the cystic duct to the sphincter of Oddi. Each of these propagated bursts started on the cystic duct $0.81 \pm 0.22 \mathrm{sec}$. before the occurrence of an isolated burst on the duodenal bulb, which was propagated in the duodenum to beyond the ligament of Treitz. This burst arrived at the choledoco-duodenal junction $0.43 \pm 0.11 \mathrm{sec}$. after that propagated from the cystic duct to the common bile duct had reached the last biliary electrode site, i.e. at about $4 \mathrm{~cm}$ from the sphincter. This was the main propagation pattern observed for this activity since more than $87 \mathrm{p}$. 100 of the bursts in the biliary tract were associated with the propagation of duodenal bulb activity. The cyclical periods of quiescence of the duodenal bulb and the antrum following the occurrence of bursts in series on the duodenal bulb associated with the duodenal development of RSA were concurrent with the lowest spiking activity level of the biliary tract (fig. 3).

Electro-mechanical relationship. - Simultaneous recording of the electrical and mechanical activities of the gallbladder corpus showed that the phases of electrical activity were associated with a slow increase in the muscular tone reaching a tension of approximately $2 \mathrm{~g}$ between the two fixing points of the strain gauge. These oscillations of the basal tension were observed predominantly in the case of cyclic activity (type A) of the gallbladder.

Rapid low amplitude oscillations, not individually correlated with bursts of potentials were superimposed on slow variations of tension. The amplitude of slow

FIG. 1. - Electrical activity of the ewe gallbladder. The potentials (spikes) of the apical pole appear in series (A) or dispersed (B) ; their mean frequency is 24 and 5 potentials/min., respectively. Isolated potentials appear randomly on the neck; bursts often occur at the end of an active apex phase.

FIG. 2. - Biliary tract and antro-duodenal electromyographic relationships. Potential bursts of the cystic duct are propagated until the distal part of the common bile duct, preceding (a) the corresponding duodenal bulb activity (b) by $0.8 \mathrm{sec}$. The common bile duct shows local perstaltic and antiperistaltic propagated bursts.

FiG. 3. - Cyclical organization of biliary tract and duodenal electrical activity. Spiking activity $(>3 \mathrm{~Hz})$ is summed at $20-\mathrm{sec}$ intervals and expressed in microcoulombs $(\mu C)$. The gallbladder apex shows cycles of rhythmic activity with a frequency of 4-5/hour greater than that of the myoelectric complexes originating on the duodenal bulb. The common bile duct activity is cyclically inhibited at the occurrence of regular spiking activity phases (RSA) associated with an antral spiking inhibition. 
variations of tension on the gallbladder was not linked with that of the potentials or their frequency. Basal tension was maximal when antral activity was reduced and its slow variations were attenuated (fig. 4). During a prolonged fasting period ( $72 \mathrm{hrs}$ ) the cyclic activity disappeared with a progressive reduction of the number of rapid potentials in the gallbladder apex during the first $24 \mathrm{hrs}$ of fasting. Refeeding was followed by a restoration of the cyclic pattern in 36 to $48 \mathrm{hrs}$.

Effect of CCK-PZ and CCK-OP. - The administration of CCK-PZ $(0.5 \mathrm{IU} / \mathrm{kg} \mathrm{IV)}$ In fed animals induced an immediate series of spike bursts in the gallbladder lasting $1.5 \mathrm{~min}$. which was followed by an high frequency of potentials during 4 to 6 min. after the injection (fig. 5).

Increasing the dose from 0.5 to $4 \mathrm{lU} / \mathrm{kg}$ did not present a dose-effect relationship. On the contrary, at $4 \mathrm{lU} / \mathrm{kg}$ a reduction in the gallbladder motor response was observed (table 2). During a slow intravenous infusion of CCK-PZ $(1 \mathrm{IU} / \mathrm{kg})$ the cyclic organization of the gallbladder activity was abolished and replaced by a continuous disorganized high level activity with potentials occuring at a frequency of $24.5 \pm 2.1 \mathrm{~min}$., the normal cyclic pattern being restored at the end of the infusion (fig. 6). During CCK-PZ infusion, the electrical activity of the common bile duct was reinforced by an increase in the frequency of propagated bursts. Concurrently, the duodeno-jejunal electromyogram showed a continuous irregular activity phase. Such effects did not persist beyond the period of infusion (fig. 6).

TABLE 2

Effect of infravenous CCK-PZ and CCK-OP administration on spiking activity frequency of the ewe gallbladder

\begin{tabular}{|c|c|c|c|c|}
\hline \multirow{2}{*}{ Treatment } & \multirow{2}{*}{$\begin{array}{l}\text { Dose } \\
(/ \mathrm{kg})\end{array}$} & \multicolumn{2}{|c|}{ Mean number per $\min \left({ }^{a}\right)$} & \multirow{2}{*}{$\begin{array}{l}\text { Duration }(b) \\
\quad(\min )\end{array}$} \\
\hline & & Control & Response & \\
\hline $\begin{array}{l}\text { CCK-PZ }(n=5) \quad \ldots \ldots \\
\text { CCK-OP }(n=5) \quad \ldots \ldots\end{array}$ & $\begin{array}{l}0.5 \mathrm{U} \\
1 \\
4 \\
0.1 \mathrm{mcg} \\
0.2\end{array}$ & $\begin{array}{l}4.3 \pm 1.5 \\
5.5 \pm 2.3 \\
4.6 \pm 3.4 \\
3.5 \pm 1.4 \\
6.5 \pm 1.2\end{array}$ & $\begin{array}{l}16.2 \pm 2.8\left({ }^{1}\right) \\
15.3 \pm 2.6\left({ }^{1}\right) \\
10.5 \pm 3.1\left({ }^{1}\right) \\
6.6 \pm 1.8\left(^{(1)}\right. \\
8.5 \pm 2.1\end{array}$ & $\begin{array}{r}5.2 \pm 1.9 \\
4.2 \pm 1.4 \\
4.6 \pm 2.1 \\
10.4 \pm 2.3 \\
8.2 \pm 1.4\end{array}$ \\
\hline
\end{tabular}

(a) 0.5-4 min after administration of CCK-PZ and CCK-OP.

$(b)$ Determined by a non-significant frequency $(P=0.05)$ if compared to control values at 20-sec intervals.

(1) Significanfly different $(P<0.05)$ from control values.

The intravenous bolus injection of CCK-OP induced both a primary series of continuous potentials followed by an increase in the spike occurrence similar to that observed for CCK-PZ (table 2, fig. 5). The maximal primary response was obtained at a dose of $0.1 \mu \mathrm{g} / \mathrm{kg}$ and was approximately half of that observed for CCK-PZ at $0.5 \mathrm{IU} / \mathrm{kg}$; in all cases the increase in frequency lasted $10.4 \pm 2.3 \mathrm{~min}$. vs. $4.2 \pm 1.4 \mathrm{~min}$ for CCK-PZ. 
(4)
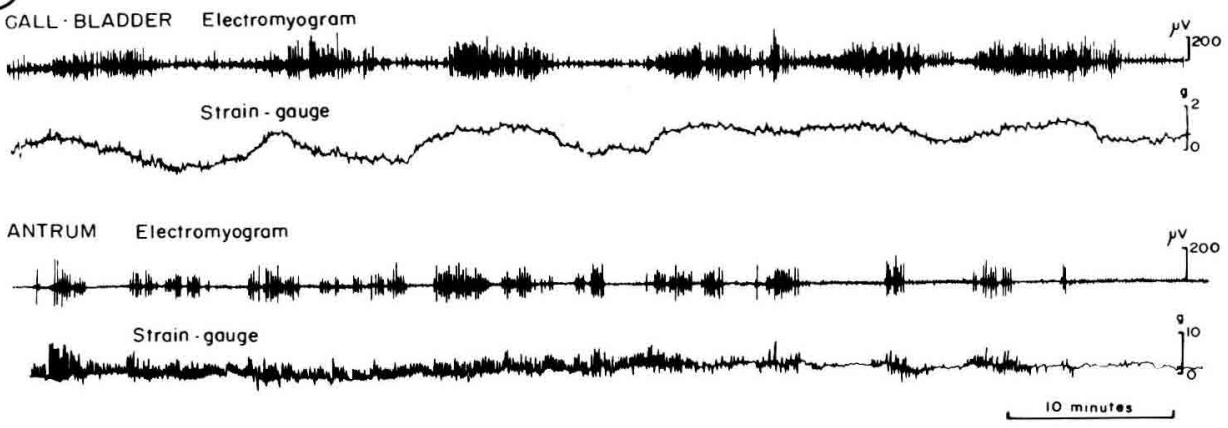

(5)
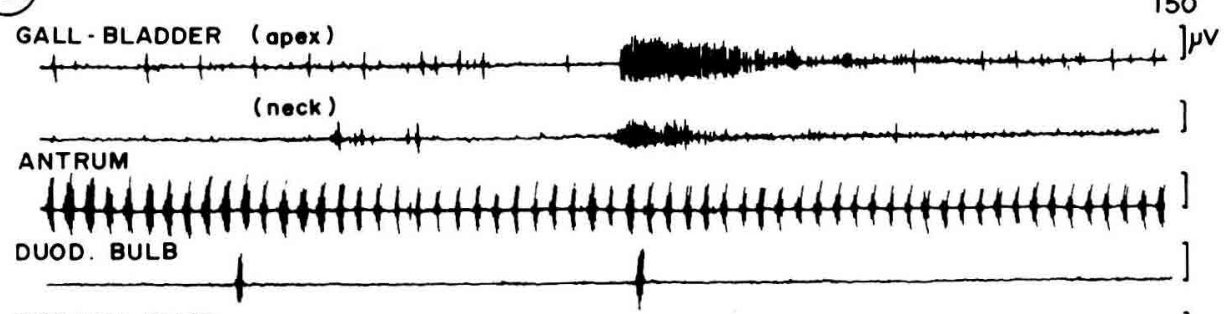

TRANSV. DUOD.

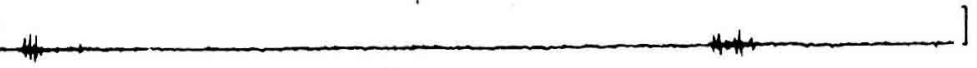

CCK.PZ 0.5 I.U. $\mathrm{kg}^{-1}$ I.V.
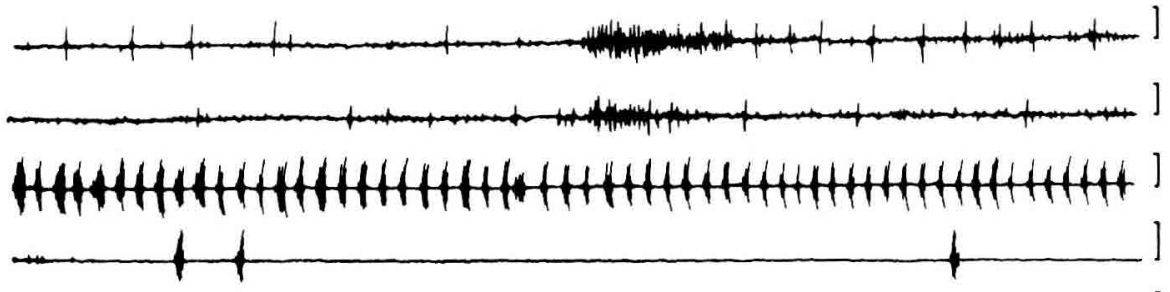

CCK - OP $0.1 \mu g \cdot \mathrm{kg}^{-1}$ I.V.

$1 \mathrm{~min}$

FIG. 4. - Comparative electromechonical relationships on the sheep gallbladder and ontrum. The period of spiking activity recorded in the gallbladder wall corresponds only fo slow changes (about $2 \mathrm{~g}$ ) in wall tension; the main effect is an increase in basal tone. At the antral level, each burst on the antrum is associated with phasic contractions of the wall $(10 \mathrm{~g})$ but the basal tone does not vary much.

FIG. 5. - Effect of CCK-PZ and CCK-OP bolus injection on gallbladder and antro-duodenal electrical activify. Note the selective hyperactivity immediately produced in the gallbladder by both substances. 
Acidification of the duodenum by slow perfusion of $\mathrm{HCl}(0.1 \mathrm{~N})$ did not reproduce the effects of CCK. The cycles of gallbladder activity were not disrupted but, on the contrary, were reinforced from $30 \mathrm{~min}$. to $2 \mathrm{hrs}$ after the end of the infusion period (fig. 6). The common bile duct and the duodenum presented an hyperkinesia during the 20-30 first minutes of perfusion ; this excitatory effect was followed by a reduction in the total activity associated with an increase in the duodenal apparition of the regular spiking activity at only 40-50 min. intervals in place of $97 \pm 13 \mathrm{~min}$.

Sympathomimetic drugs. - At $3 \mathrm{mcg} / \mathrm{kg}$ IV, adrenaline suppressed gallbladder spiking activity for 3 , to $4 \mathrm{~min}$. as well as that of the antrum and duodenum (fig. 7 ). This response was particularly marked for the apex as compared to the neck but the spiking activity reappeared earlier at the apex, and a normal frequency of spikes was obtained within $10 \mathrm{~min}$. after injection (table 3). Similar but prolonged (6-7 min.) effects were obtained with isoprenaline $(5 \mathrm{mcg} / \mathrm{kg}$ ) (table $3, \mathrm{fig} .7)$. On the contrary,

\section{TABLE 3}

Comparative effects of adrenergic and anticholinergic drugs on gallbladder electrical activity in sheep

\begin{tabular}{|c|c|c|c|c|c|c|}
\hline & \multirow{2}{*}{$\begin{array}{r}\text { Time } \\
(+\mathrm{sec})\end{array}$} & \multicolumn{5}{|c|}{ Number of spikes per min } \\
\hline & & $\begin{array}{l}\text { Adrenalin } \\
(3 \mathrm{mcg} / \mathrm{kg})\end{array}$ & $\begin{array}{l}\text { Isoprenaline } \\
(5 \mathrm{mcg} / \mathrm{kg})\end{array}$ & $\begin{array}{l}\text { Neosynephrine } \\
(150 \mathrm{mcg} / \mathrm{kg})\end{array}$ & $\begin{array}{l}\text { Neostigmine } \\
(30 \mathrm{mcg} / \mathrm{kg})\end{array}$ & $\begin{array}{c}\text { Atropine } \\
(0.1 \mathrm{mg} / \mathrm{kg})\end{array}$ \\
\hline $\begin{array}{l}\text { Control } \\
(n=5) \\
\text { After injec- }\end{array}$ & -30 to 0 & $6.2 \pm 1.4$ & $5.7 \pm 2.0$ & $4.7 \pm 1.5$ & $3.2 \pm 1.4$ & $6.1 \pm 2.1$ \\
\hline 5) $\ldots \ldots$ & 30 to 60 & $1.9 \pm 0.8\left({ }^{1}\right)$ & $1.8 \pm 0.6\left(^{1}\right)$ & $15.3 \pm 5.1\left({ }^{1}\right)$ & $6.9 \pm 0.8\left({ }^{1}\right)$ & $1.5 \pm 0.7\left({ }^{1}\right)$ \\
\hline
\end{tabular}

(1) Significant difference with control values $(P<0.05)$.

phenylephrine $(150 \mathrm{mcg} / \mathrm{kg})$ induced gallbladder hyperactivity corresponding to a 3-4 min. increase of about 400 p. 100 in the occurrence frequency of gallbladder rapid potentials.

Effects of neostigmine and atropine. - The frequency of gallbladder rapid potentials was increased by 53 p. 100 , reaching a mean value of 6.9 potentials $/ \mathrm{min}$ instead

FIG. 6. - Comparative effects of CCK-PZ intravenous infusion and duodenal acidification on patferns of the ewe biliory and intestinal tract. Note that intravenous infusion of CCK disrupts the cyclic pattern and replaces it by a continuous spiking activity, while duodenal acidification first reduces the occurrence of intestinal migrating myœlectric complexes with a transient reduction of the gallbladder activity at the end of the infusion. These effects are followed by an increase in the duodenal apparition of the regular spiking activity.

FIG. 7. - Effects of adrenergic and anticholinergic drugs on gallbladder and antro-duodenal electrical activity. Note the opposite effects of phenylephrine $(\alpha$-mimetic) and isoprenaline ( $\beta$-mimetic) on the gall-bladder spiking level. Atropine and adrenaline inhibit gallbladder potential activity. 
(6)

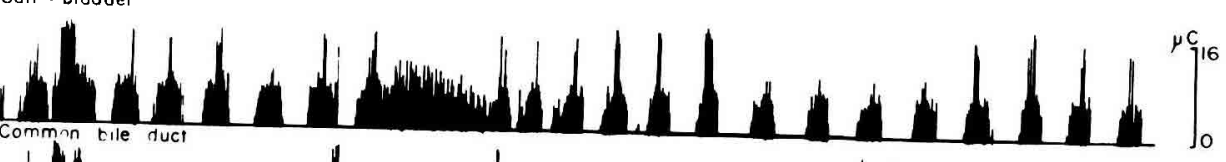

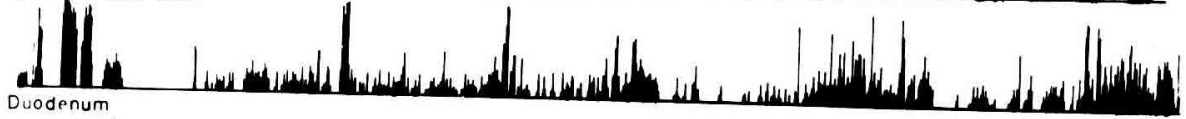

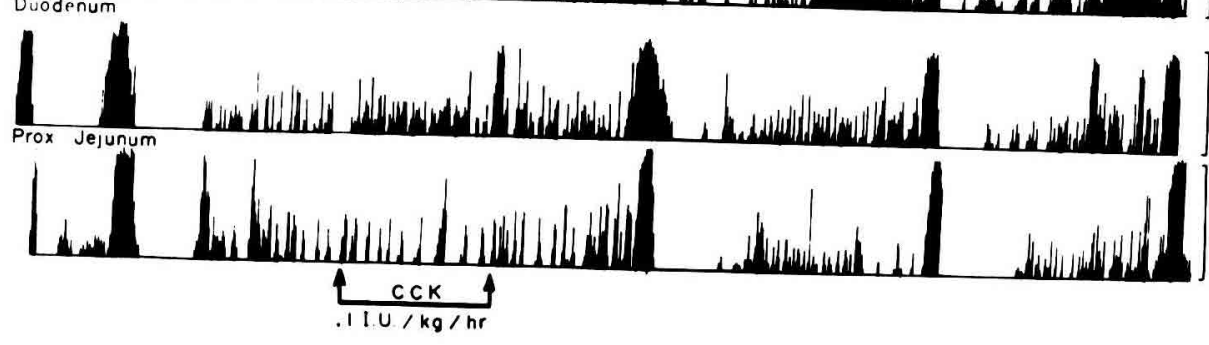

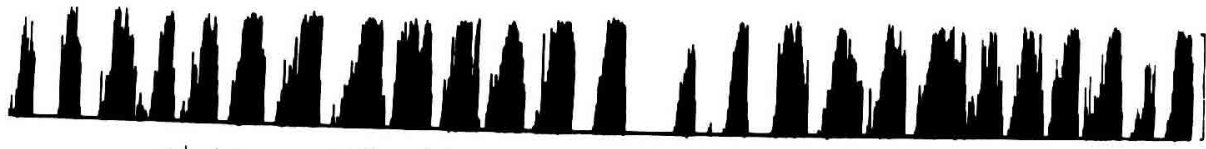

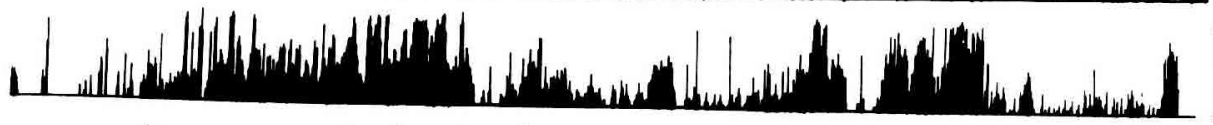

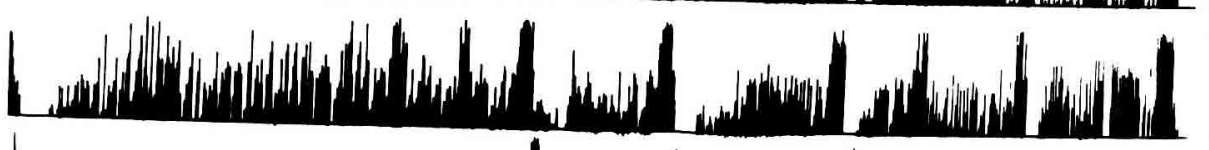

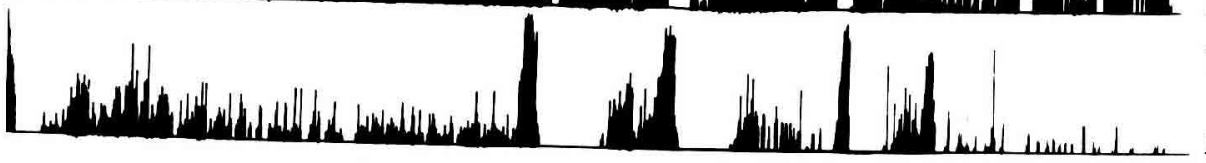

$$
\frac{\mathrm{HCl} O . \mathrm{IN}}{2 \mathrm{ml} / \mathrm{min}}
$$

GALL : BLADDER (ODEX)

7

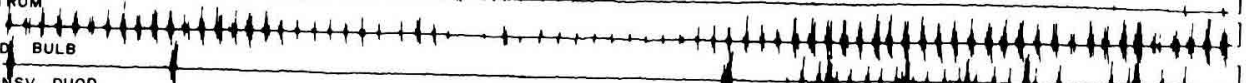

ougo BULB

- Adrenalin $3 \mu \mathrm{g} \cdot \mathrm{kg}^{-1} \mathrm{I} . \mathrm{V}$.

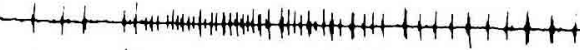

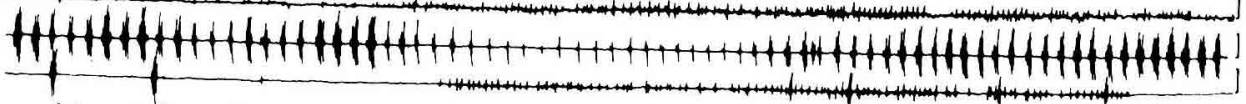

- Phenyiephrine $150 \mu \mathrm{g} \cdot \mathrm{kg} \cdot 1$

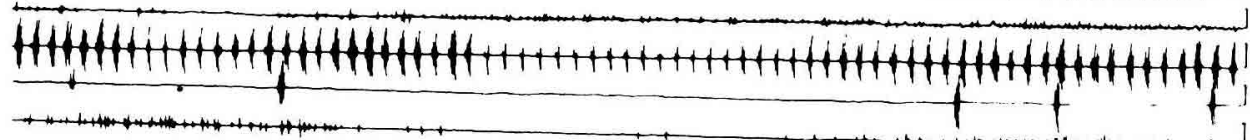

- Isoprenaline $5 \mu g \cdot \mathrm{kg}^{-1} \mathrm{I} . \mathrm{V}$.

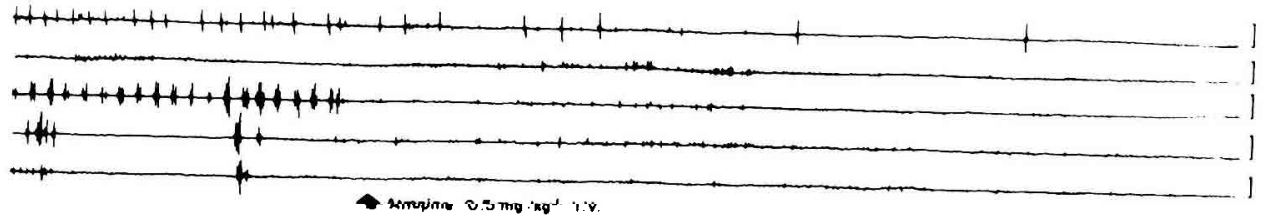


of 3.2 from 30 to $60 \mathrm{sec}$, following administration of neostigmin $(30 \mathrm{mcg} / \mathrm{kg})$ (table 3 ). On the contrary, atropine suppressed this spiking activity for 1.5-2 hrs at a dose of $0.5 \mathrm{mg} / \mathrm{kg}$ (fig. 7, table 3). These effects were limited to $40-50 \mathrm{~min}$. with a dose of $0.1 \mathrm{mg} / \mathrm{kg}$.

\section{Discussion.}

This work demonstrates the existence of electrical activity in the wall of the gallbladder in sheep, associated with slow variations of its wall tension in accordance with the cyclic changes in intraluminal pressure previously described by Caple and Heath (1971) for this species. These findings differ from those of Ludwick and Bass (1967) who did not defect any electrical activity in dogs or the monkeys, observing only pressure changes after feeding. However, neither the frequency patterns of the potentials recorded at the apical pole nor those of the body and the neck of the gallbladder can be attributed to a duodenal (Klimov and Kotelnikova, 1973) or an antral rhythm, as proposed by Laplace (1976) for pigs. No fundamental anatomical difference has been determined in the gallbladder structure of sheep (Schreiber, 1941) which would explain the selective presence of electrical activity in the organ of that species as compared to other species.

A striking feature is the presence of an apex cyclic activity which cannot be correlated with that of the other parts of the biliary and duodenal tracts. It is commonly accepted that bile formation is due to a combination of continuous (basal) secretion and cyclic-adaptive changes in relation to other digestive glands. In ruminants the delivery of bile into the duodenum increases the volume of the bile secreted, while emptying the reticulo-rumen reduces the secretory rate (Harrison, 1962). In ad libitum-fed animals, a cyclic contraction wave of the apex can be considered as a motor adaptation to changes in bile volume as a consequence of secretory waves. This hypothesis is reinforced by the disappearance of this response under starvation.

The presence of a specific electrical activity of the cystic and common bile ducts in sheep agrees with the rhythmic, spontaneous, mechanical activities recorded for the extrahepatic biliary tract of other species in vitro (Tooli and Watts, 1970) as well as in vivo in anaesthetized (Tansy et al., 1971) or conscious dogs (Doyle and Farrar, 1965).

The propagation of spike bursts along the common bile duct was coordinated with that of the corresponding duodenal bulb activity. Taking into account the earlier arrival of the former at the sphincter of Oddi, it seems likely that bile is delivered to the intestine just before each digesta bolus.

The continuous spike activity of the neck, associated with that propagated by the cystic duct after a spiking activity period of the apex, may serve as a backflow preventing reflex.

The stimulatory motor action of CCK observed in humans (Park et al., 1970) and in dogs (Ivy and Oldberg, 1928) increases gallbladder spiking activity in accordance with an increase in pressure as observed by Caple and Heath (1971) in sheep. The absence of dose-effect relationships agrees with the pressure recordings of Pass and Heath (1977), suggesting the intervention of a biochemical mechanism at the origin of 
the on-off response. According to Robison et al. (1971), CCK may act at the level of smooth muscle cells by way of cAMP.

Duodenal acidification acts as a CCK-releasing factor; however, the different characteristics of the gallbladder motor responses observed for acid and CCK suggested that other factors may modulate this response in sheep.

In vivo assays on dogs to measure the relative potency of CCK-OP on induced gallbladder contractions, as compared to purified extracts of CCK, have shown that $1 \mathrm{mg}$ of CCK-OP is equivalent to 27 lvy Dog Units of CCK. In this investigation, an equivalent gallbladder spiking response was obtained for 0.5 IDU of CCK and $0.2 \mu \mathrm{g}$ of CCK-OP per $\mathrm{kg}$ of body weight, corresponding to a 92-fold greater potency for CCK-OP (1 $\mathrm{mg}$ of CCK-OP is equivalent to 2500 IDU of CCK).

Nervous control of gallbladder activity in sheep does not differ from that of cats with respect to the effects of adrenergic and cholinergic drugs. A distinction could be made between the effects of excitory $\alpha$ mimetics and inhibitory $\beta$ mimetics when phenylephrine and isoprenaline were administered (Crema ef al., 1969). The net inhibitory response obtained with adrenaline may be attributed to the low proportion of $\alpha$ receptors in the gallbladder (Persson, 1972), as well as to the sensitivity level of the two kinds of receptors. The excitatory action of neostigmin on electrical spiking activity concurs with the pressure changes observed in sheep after acetylcholine administration (Hallenbeck, 1967) and during vagal stimulation (Pass and Heath, 1977).

Reçu en décembre 1978.

Accepté en mars 1979.

Résumé. L'activité électrique de la vésicule, du tractus biliaire, de la zone antro-duodénale a été enregistrée pendant 4 à 6 semaines chez 6 brebis adultes à partir d'électrodes intrapariétales fixées à demeure. Chez trois sujets, les électromyogrammes de la vésicule et de l'antre ont été comparés aux mécanogrammes obtenus à partir de jauges de contrainte placées au même niveau.

L'électromyogramme de la pointe de la vésicule biliaire est constitué de potentiels rapides $(0,5-1,5 \mathrm{~s})$ isolés dont le développement en série de 40 à 50 pendant $6,2 \pm 1,9 \mathrm{mn}$ a lieu 4 à 5 fois par heure et correspond pour chacun des cycles à des élévations lentes de la tension pariétale. Au niveau du col de la vésicule, ce type de potentiels est moins fréquent mais persiste associé à une activité phasique de potentiels groupés en 10 à 12 salves intervenant à la fin d'une période d'activité cyclique de la zone apicale.

L'électromyogramme cysto-cholédocien présente, toutes les 80-120 s, 1 ou 2 salves de potentiels propagées $(7 \mathrm{~cm} / \mathrm{s})$ et associées aux activités cycliques du bulbe et du duodénum. La formation de chacune de ces salves au niveau du canal cystique par rapport au bulbe duodénal assure un décalage de $0,4 \mathrm{~s}$ entre l'arrivée de ces salves à proximité du sphincter d'Oddi, d'où un déversement intra-duodénal de bile précédant l'arrivée du contenu duodénal.

L'administration intraveineuse de CCK-PZ $(0,5$ à $4 \mathrm{IDU} / \mathrm{kg})$ au même titre que celle de CCK-OP $(0,1$ et $0,2 \mathrm{mcg} / \mathrm{kg})$ procure une riposte motrice de la vésicule avec une phase primaire de potentiels groupés durant 60-80 s suivie d'une période d'augmentation (5$10 \mathrm{mn}$ ) de la fréquence des potentiels, $1 \mu \mathrm{g}$ de CCK-OP ayant des effets équivalents à ceux de 2,5 IDU de CCK-PZ (GIH). La perfusion intraveineuse lente de CCK-PZ $(1 \mathrm{IDU} / \mathrm{kg} / \mathrm{h})$ ne procure que la réponse secondaire avec une augmentation de 42 p. 100 de la fréquence des potentiels de la vésicule. 
Enfin, l'administration de sulfate d'atropine $(0,1 \mathrm{mg} / \mathrm{kg})$ au même titre que celle d'adrénaline $(3 \mathrm{mcg} / \mathrm{kg})$ ou d'isoprénaline $(5 \mathrm{mcg} / \mathrm{kg})$ abolif l'activité rapide vésiculaire alors que l'administration de phényléphrine la renforce. Ces résultats suggèrent un effet stimulant des substances cholinergiques et $\alpha$ adrénergiques alors que la stimulation des récepteurs $\beta$ adrénergiques est inhibitrice de la motricité vésiculaire.

En définitive, ce travail permet de conclure que la vésicule biliaire possède une activiłé électrique organisée correspondant à des contractions toniques de la paroi non liées à la motricité cysto-cholédocienne et duodénale, à l'exception d'une zone réduite au niveau du col.

Contrôlée sur le plan hormonal par la CCK-PZ, cette fonction motrice est néanmoins dépendante d'une innervation cholinergique et $\alpha$-mimétique excitomotrice et $\beta$-mimétique inhibitrice.

\section{Références}

BOYDEN E. A., 1965. The biliory Sysiem, 15-40, Blackwell Sci. Publ., Oxford.

BUENO L., FIORAMONTI J., RUCKEBUSCH Y., 1975. Rate of flow of digesta and electrical activity of the small intestine in dogs and sheep. J. Physiol., Lond., 249, 69-85.

CAPLE I., HEATH T. J., 1971. Function of the gall-bladder in sheep. Quart. J. exp. Physiol., 56, 197-209.

CAROLI J., PORCHER P., PEQUIGNOT G., DELATTRE H., 1956. Contribution du radiocinéma à l'étude du fonctionnement des voies bilidires de l'homme. Sem. Hôp. Paris, Ann. Rech. méd., 32, 975-1000.

CREMA A., BENZI G., FRIGO G. M., BERTE F., 1969. Occurrence of alpha and beta receptors in the bile duct. Proc. Soc. exp. Biol. Med., 120, 158-160.

DOYLE J. S., FARRAR J. T., 1965. Biliary piazograms and heisterian sphincter. Gostroenterology, 48, 864-865.

HALLENBECK G. A., 1967. Biliary and pancreatic intraductal pressures. In HEIDEL W., Code C. F. Handbook of Physiology, Alimentary Canal, T. II, 1007-1025. Am. Physiol. Soc., Washington.

HARRISON F. A., 1962. Bile secretion in the sheep. J. Physiol., Lond., 162, 212-224.

IVY A. C., OLDBERG E., 1928. A hormone mechanism for gall-bladder contraction and evacuation. Am. J. Physiol., 85, 599-613.

KLIMOV P. K., KOTELNIKOVA V. I., 1973. The bioelectric activity of the gall-bladder sphincters of the biliary tract and the central part of the stomach (in Russian). Fiziol. Zh. Sechenov., 59, 140-155.

LAPLACE J. P., 1976. L'excrétion biliaire chez le porc. 1) Electromyographie des voies biliaires extra-hépatiques. Rec. Méd. vét., 152, 33-43.

LATOUR A., 1973. Un dispositif simple d'analyse quantitative de l'électromyogramme intestinal chronique. Ann. Rech. véfér., 4, 347-353.

LUDWICK J. R., BASS P., 1967. Contractile and electric activity on the extra-hepatic biliary tract and duodenum. Surg. Gynecol. Obstet., 124, 536-546.

MAGEE D. F., 1965. Physiology of the gall-bladder emptying, 233-247. In TAYLOR W., The biliory system. Blackwell Sci. Publ., Oxford.

MALLET-GUY P., AUGER L., CROIZAT P., 1973. Etude expérimentale de la section du sphincter d'Oddi. Revue Chir., 16, 239-267.

NEJMARK L., 1977. The functions of bile ducts in sheep. Acta physiol. pol., 28, 463-474.

PARK C. Y., PAE Y. S., HONG S. S., 1970. Radiological studies on emptying of human gali-blacider. Ann. Surg., 171, 294-299.

PASS M. A., HEATH T. J., 1977. Factors affecting gall-bladder motility in sheep. Comp. biochem. Physiol., 56, 127-131.

PERSSON C. G. A., 1972. Adrenergic, cholecystokinetic and morphine-induced effects on extrahepatic biliary motility. Acta physiol. scand., Suppl. 383, 1-32.

ROBISON G. A., BUTCHER R. W., SUTHERLAND E. W., 1971. Cyclic AMP. Acad. Press New York and London. 
RUCKEBUSCH Y., 1973. L'électromyographie globale des muscles lisses à parfir d'électrodes chroniques intrapariétales souples. Rev. Méd. vét., 124, 1407-1434.

SARLES J. C., MIDEJEAN A., DEVAUX M. A., 1975. Electromyography of the sphincter of Oddi, technic and experimental results in the rabbit : effect of certain drugs. Am. J. Gastroenterol., 63, 221-231.

SCHREIBER H., 1941. Das Muskellager der menschlichen Gallenblasenwand im Vergleich zu der vierfüssiger Saüger. Z. Anat. Entwickl. Gesh., 111, 91-150.

TANSY M. F., HACKOWIACK R. C., CHAFFEE K. B., 1971. A vago-sympathetic pathway capable of influencing common bile duct motility in the dog. Surg. Gynecol. Obsfet., 133, 225-236.

TOOLI J., WATTS J. M. K., 1970. The spontaneous motility and the action of cholecystokinin pancreozymin, secretin and gastrin on the canine extra-hepatic biliary tract in vitro. Br. J. Surg., 57, 858 (abstr.).

WYATT A. P., 1967. The relationship of the sphincter of Oddi to the stomach, duodenum and gallbladder. J. Physiol., Lond., 193, 225-243. 